\title{
Tourism Development in Langsa, Indonesia: An Overview of Tourist Attractions and Accommodation
}

\author{
Nurlina \\ Department of Development Economics, Faculty of Economics, Universitas Samudra, Aceh, Indonesia \\ nurlina@unsam.ac.id
}

\begin{abstract}
This study provides an overview of the development of tourism destinations, precisely tourist attractions and accommodation in Langsa, Indonesia. Data collection in this research through secondary data collection at related institutions and data analysis descriptively qualitative. The results of this study indicate that there are six main tourist objects. The number of tourist visits by attractions from month-over-month during the year 2016, increasing. The most visited attractions are the city forest park, mangrove forests, culinary centers, Vitra Tirta Raya Swimming Pool, and Mutiara Water Park. The increase in the number of visits this tour, especially on tourist objects managed by government companies caused by the better management of tourism and its supporting facilities. The Municipal Government of Langsa has sought to develop tourism with all its facilities to address several development challenges, including poverty reduction, local economic development, and sustainability.
\end{abstract}

\section{Keywords}

tourism destination;

tourism development;

tourist accommodation;

tourist attractions

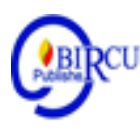

\section{Introduction}

The development of the tourism sector has unified in the National Medium Term Development Plan 2010-2014 (RPJMN 2010-2014) and strengthened through Government Regulation No. 50 of 2011 on the National Tourism Development Master Plan, which contains the vision, mission, goals, targets, and direction of national tourism development 2010-2025. With the regulation, the development of the tourism sector from planning, implementation, and evaluation can well; it can be sure it will increase the number of tourist visits from foreign tourists to Indonesia.

With the increase of international tourist arrivals, it will have an impact on the increasing amount of tourism receipts revenue for Indonesia. Also, it will place the tourism sector as one of the commodities that can generate the most significant tourism receipts. This will have a direct impact on the development of Indonesia's micro and macroeconomic foundations.

Table 1. Tourism Receipts in Indonesia, 2011-2015

\begin{tabular}{cc}
\hline Year & Tourism receipts (Million USD) \\
\hline 2011 & $8,554.39$ \\
2012 & $9,120.85$ \\
2013 & $10,054.15$ \\
2014 & $11,166.13$ \\
2015 & $12,225.89$ \\
\hline
\end{tabular}

Source: Tourism Satellite Account, Ministry of Tourism, Indonesia, 2016 
The position of the tourism sector among the 11 most substantial commodity goods export categories since 2011-2015 has increased. In 2011 and 2012, the tourism sector is ranked the fifth-largest contributor to the country's tourism receipts. But in the year 20132015 increased again to be in the fourth position of tourism receipts contributors to the country. This can show in Table 1.2, which illustrates the increase in tourism receipts contributions of the State. Therefore, the tourism sector is a very potential sector for the economic empowerment of the people and has a significant multiplier effect. The development of national tourism is directed to a leading industry of excellence and superiority that translates into the most critical tourism receipts that will boost economic growth, increase local revenues, empower the economy of the community, expand employment and business opportunities.

It was later realized that the tourism trend was shifting in interest. Modern tourism trends are also increasingly interested in domestic society is to find the uniqueness of the natural environment and culture. Conserving the diversity of biological resources and local cultural peculiarities is the best way to attract more tourists, which in turn will benefit the global economy. Along with the growth of the tourism industry, the demand for tourists to various destinations is increasing. In its development, the destination area needs to be equipped with various supporting facilities in order to provide comfort to the tourists. So do not just rely on the natural environment and beautiful scenery, but also must be equipped with various other supporting facilities.

\section{Review of Literature}

Tourism is one of the determinants of national economic growth because it can influence the growth of other sectors in the economy (Gokovali \& Bahar, 2006) and also grows very fast during this decade (Dogru \& Bulut, 2018; Wu et al., 2000). Sustainable tourism development can be completed by creating opportunities through networking and cooperation with service providers, where stakeholder engagement, the development of locally oriented codes of conduct, and local government participation are crucial factors for sustainable tourism success (Welford \& Ytterhus, 2004). A sustainable tourism approach should prove more useful for people who are very sensitive to global environmental and economic changes, such as rural-based rural tourism communities in coastal and alpine areas of the world (Amir et al., 2015). If tourism continues to contribute positively to sustainable rural development, it is imperative to have a better understanding of this dependency. The value of tourism experience will undoubtedly decrease if the tourism industry and its stakeholders ignore this resource base, and in turn, so the rural tourism industry itself (Amir et al., 2015). According to Amin (2019) the advantage of the tourism sector lies in its ability to increase foreign exchange and to drive various other business sectors such as the home industry. Thus, developed countries and developing countries continue to develop and improve the quality of their country's tourism.

In the development of the tourism sector, the government needs attention to the empowerment of the community in the field of tourism with the benefits derived from the community from the development so as to improve the image and public confidence to the local government (Nunkoo, 2015). In addition, if the tourism sector is well managed and developed, it can also have favorable political effects for local governments, such as increasing their legitimacy of the population and an essential lesson for the government (Nunkoo, 2015). 
To improve the competitiveness and development of sustainable tourism destinations, the presence of tourism products is a crucial factor that can attract more tourists to tourist destinations (Benur \& Bramwell, 2015; Alves et al., 2015). The findings in Brazil show that factors affecting sustainable tourism competitiveness consist of tourism infrastructure, information an communication technology infrastructure, education, cultural heritage, socioeconomic development, and environmental preservation (Alves et al., 2015). Syahrin (2018) states language and culture are two systems inherent in humans. Language as a system that regulates human intraction in society while language as a means of carrying out the intraction. Language is often regarded as a cultural product even an inseparable part of the two things. As a cultural product, language is certainly a forum for cultural aspirations, activities, and community behavior. Cultural disclosures include technology created by the community using the language. Cultural destinations can enhance and improve the effective interaction between tourists and hosts to enhance cultural exchanges and provide an authentic experience to tourists, so tourists can recommend their family and friends to visit the tourist destinations they have visited (Chen \& Rahman, 2017).

To attract more tourist interest and the longer stay in tourist sites, tourism development needs to develop commodities, tourist monuments, leisure activities, and other tourist activities (Ben Aissa \& Goaied, 2017). The slogan of the tourist destination as a tourism brand is crucial to convey a message to tourists to increase its appeal (Galí et al., 2017). Also, the openness of the population to tourist destinations can play an important role in shaping the overall support for tourism development. The findings from a survey of people living in Malaysia's tourism destination area suggest that sympathetic understanding and friendly nature are the main factors influencing citizens' attitudes towards tourism development (Moghavvemi et al., 2017). The findings in China show that the liveliness of urban community activities and other related factors dramatically contributes to the development of the tourism sector, where there is a geographical interdependence between the feasibility of urban development and tourism (Liu et al., 2017).

Indonesia has now walked the modernization era. Modernization in Indonesia is characterized by something fast, effective and efficient. Modern becomes an identity that seems to be attached to all devices of human life. The development of science and technology caused various changes in the political, social and cultural fields (Prasetyo, 2019). In the era of globalization, efficient information technology is one of the most critical and decisive elements in the development of the tourism sector, where its application depends on funds and human resources in each region. Therefore, it is the necessary introduction of information technology in companies engaged in the tourism sector to increase its market share (Kršák et al, 2014).

Findings in rural China show that entrepreneurs have unrealistic perceptions of the tourism industry before they enter, and the entrepreneurial mobility in tourism development is influenced by the dimension of social capital, through which integration with the environment can increase the contribution of entrepreneurial movement to tourism development (Zhou et al., 2017). However, the opening of various opportunities in the event of tourism also faces several challenges. The findings in Iran show that tourism actors face two major problems, namely the negative image of Iran in the Western world and the lack of resources to overcome the negative discourse (Khodadadi, 2016). 


\section{Research Methods}

This research is an applied research of pre-eminent college, with the field of the superior university that is society empowerment. Following the area of excellence, the study entitled analysis of tourism destination development in the Municipality of Langsa, Indonesia. Data collection in this study is done through secondary data collection at related institutions. Tabulation result data in this research is analyzed qualitatively. Research using a descriptive approach to describe the actual situation about the object under study. Analysis of the data is complete by stages of collecting data that has been received, analyzing data, and making data interpretation to get the conclusion.

\section{Discussion}

\subsection{Tourist Attraction and Supporting Facilities}

In supporting sustainable economic development in Langsa Municipality, the tourism sector is a potential sector to develop. Major tourist attractions in the Langsa Municipality can be observed in Table 1 below.

Table 2. Tourist Attraction

\begin{tabular}{clccc}
\hline No & Tourist Attraction & Attraction Type & $\begin{array}{c}\text { Area of } \\
\text { Attraction }\end{array}$ & $\begin{array}{c}\text { Tour } \\
\text { Management }\end{array}$ \\
\hline 1 & Mangrove Forest & Natural & $\pm 16 \mathrm{Ha}$ & Local Government \\
2 & City Forest Park & Natural & $\pm 10 \mathrm{Ha}$ & Local Government \\
3 & Bamboo Spiky Park & Special Interest & $\pm 250 \mathrm{~m}$ & Local Government \\
4 & Mutiara Water Park & Special Interest & $\pm 1 \mathrm{Ha}$ & Private \\
& Vitra Tirta Raya & & \\
5 & Swimming Pool & Special Interest & $\pm 2 \mathrm{Ha}$ & Private \\
6 & Culinary Center & Special Interest & $\pm 2 \mathrm{Ha}$ & Local Government \\
\hline Source: & Youth, Sports, Culture and Tourism Office of Langsa Municipality, Indonesia, 2017
\end{tabular}

Table 2 above it can be explained that the main tourist objects in Langsa consist of: (1) Kuala Langsa Mangrove Forest whose area reaches \pm 16 ha; (2) Forest City, has an area of \pm 10 ha; (3) Bamboo Spiky Park, with its area reaches \pm 250 m; (4) Culinary center of Langsa which has an area of \pm 2 ha. The government manages the four tourist objects through a regional company. Next (5) Pearl Water Park, which has an area of \pm 1 ha, and (6) Vitra Tirta Raya Swimming Pool, which has an area of \pm 2 ha square. Both pools are privately owned and managed.

Table 3. Supporting Facilities of Tourist Attraction

\begin{tabular}{llccccc}
\hline No & $\begin{array}{l}\text { Tourist } \\
\text { Attraction }\end{array}$ & $\begin{array}{r}\text { Parking } \\
\text { Vehicle }\end{array}$ & Toilet & $\begin{array}{c}\text { Islamic Prayer } \\
\text { Room }\end{array}$ & Cafeteria & Gazebo \\
\hline 1 & Mangrove Forest & $\sqrt{ }$ & $\sqrt{ }$ & - & - & $\sqrt{ }$ \\
2 & City Forest Park & $\sqrt{ }$ & $\sqrt{ }$ & - & - & - \\
& Bamboo Spiky & & $\sqrt{ }$ & $\sqrt{ }$ & - & $\sqrt{ }$ \\
3 & Park & $\sqrt{ }$ & $\sqrt{ }$ & $\sqrt{ }$ & $\sqrt{ }$ \\
& Mutiara Water & & $\sqrt{ }$ & $\sqrt{ }$ & $\sqrt{ }$ & $\sqrt{ }$ \\
5 & Park & Vitra Tirta Raya & $\sqrt{ }$ & $\sqrt{ }$ & $\sqrt{ }$ &
\end{tabular}




\section{Swimming Pool \\ 6 Culinary Center \\ Source: Youth, Sports, Culture and Tourism Office of Langsa Municipality, Indonesia, 2017}

Based on Table 3, it can be observed that the six main tourist objects in the Langsa Municipality, namely mangrove forest, City Forest Park, sparkling bamboo park, pearl water park, Vitra Tirta Raya Swimming Pool, and the culinary center has various supporting facilities. The supporting facilities are the parking lot, toilet, Islamic prayer room, cafeteria, and gazebo. But in the area of mangrove forest and the City Forest Park has not been available Islamic prayer room and cafeteria. In addition to the mentioned attractions, there are still other attractions, namely Balee Juang Building, Kuala Langsa Port, China Town, and Langsa Town Square (LATOS), and Merdeka Field.

\subsection{Tourists Visits by Attraction}

Number of Tourist Arrivals by Tourism Object in the Municipality of Langsa, from month to month during 2016, is presented in Figure 1. Based on Figure 1 above, it can be illustrated that, from month to month, during 2016, the number of tourist arrivals to the main tourist attraction in the Langsa Municipality increased. The most visited attractions are City Forest Park, then mangrove forests, culinary centers, Vitra Tirta Raya Swimming Pool, and Mutiara Water Park. Increased number of tourist arrivals, especially on tourist objects managed by government companies caused by the better management of tourist areas and supporting facilities.

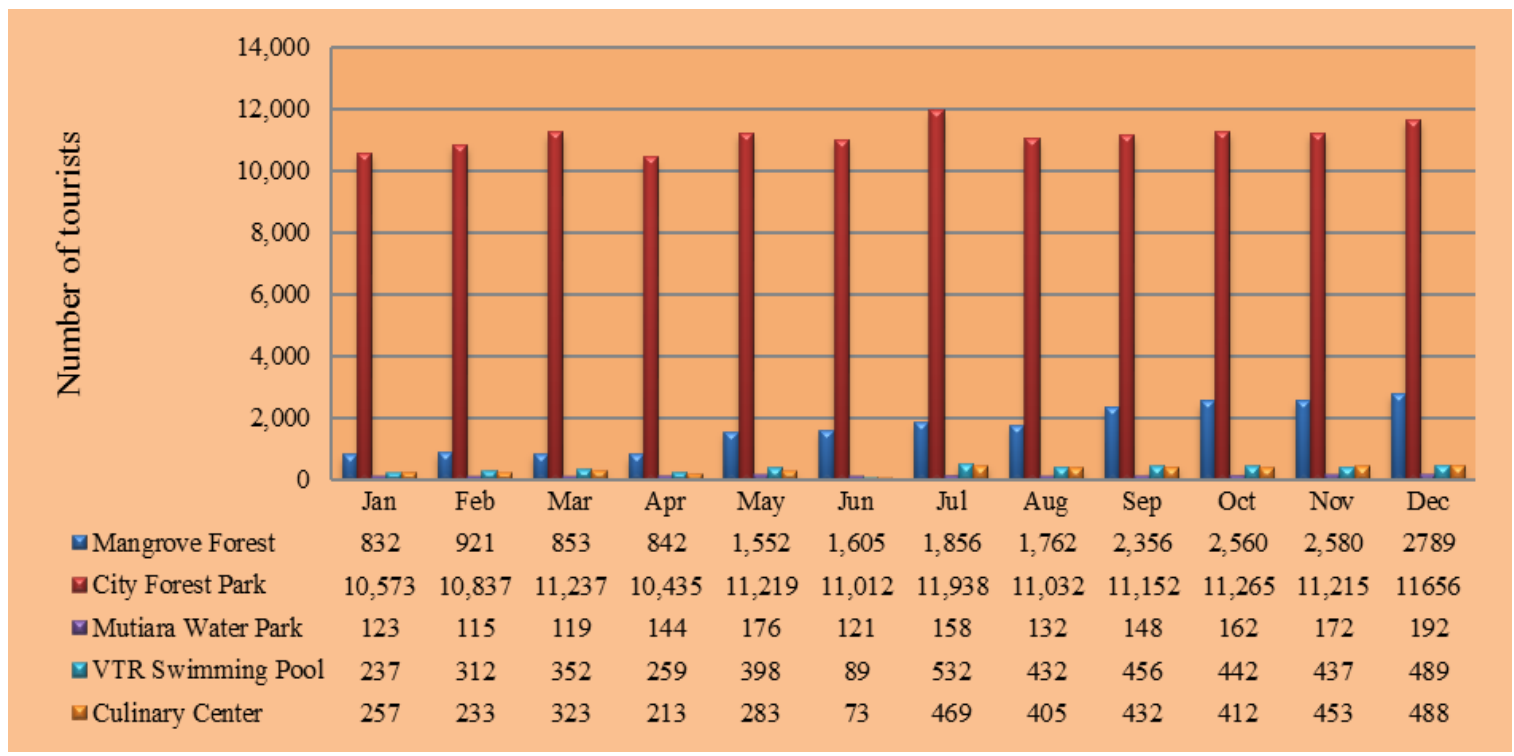

Figure 1. Number of tourist visits by attraction

Source: Youth, Sports, Culture and Tourism Office of Langsa Municipality, 2017

\subsection{Travelers by Accommodation}

The number of tourists arriving by the hotel in Langsa, month by month during 2016, is presented in Figure 2. Based on Figure 2 below, it can be illustrated that, from month to month, during 2016, the number of tourist arrivals in the Langsa Municipality is based on hotel insertion more increasing. The most famous hotel of choice is Hotel Kartika, which is also the oldest hotel in Langsa Municipality. Furthermore, the most popular hotels chosen by tourists are the Grace Hotel, Harmoni Hotel, FerlaInn Hotel, Ridho Hotel, and Kartini Hotel. 


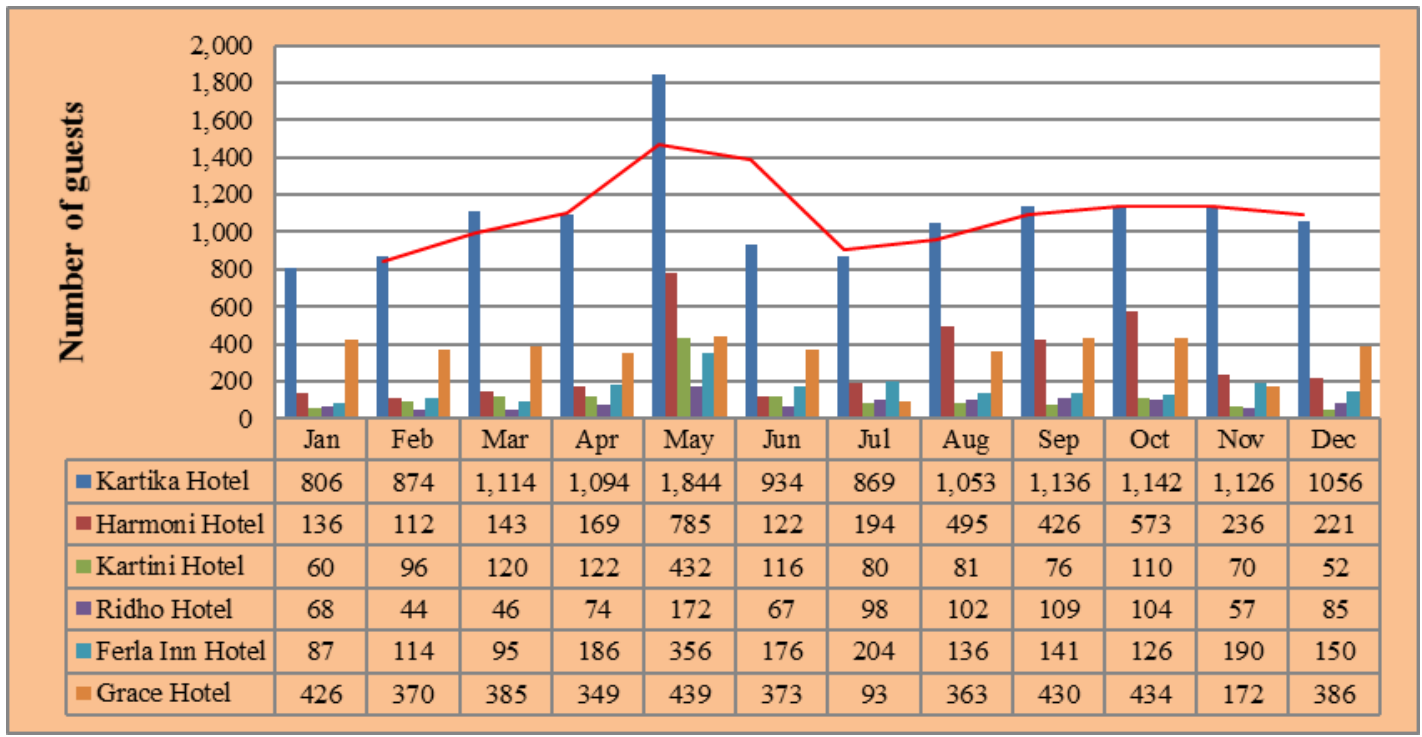

Figure 2. Number of Guests by Hotel

Source: Youth, Sports, Culture and Tourism Office of Langsa Municipality, Indonesia, 2017

The number of tourist arrivals Based on inn-based lodging in Langsa Municipality, month to month during 2016, is presented in Figure 3. Based on Figure 3 above, it can be shown from month to month, during 2016, the number of tourist arrivals in the Langsa Municipality based on inns with levels under the hotel is increasing. The most popular tourist inn is Pilar Inn. Furthermore, the most preferred guesthouse is the Pearl Inn, followed in succession by Pase Inn, Haiva Inn, and Delima Inn.

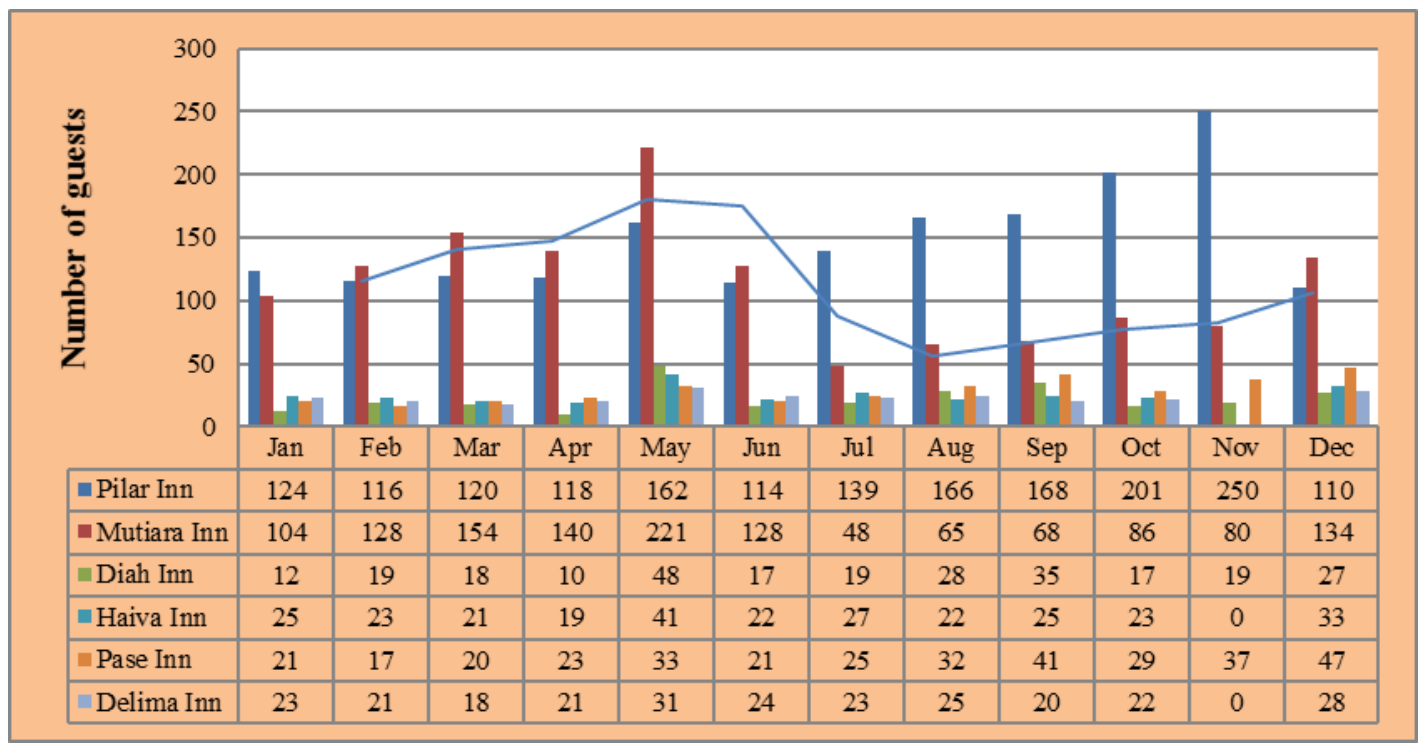

Figure 3. Number of Guests by Inss

Source: Youth, Sports, Culture and Tourism Office of Langsa Municipality, Indonesia, 2017

The number of tourist arrivals based on Inn in Langsa Municipality, month to month during 2016, is presented in Figure 4. Based on Figure 4 above, it can be described that, from month to month, during 2016, the number of tourist arrivals in the Langsa Municipality based on guesthouse also increased. The most preferred lodging is Nabila Guesthouse. Furthermore, Kost 33 Guesthouse and 88 Guesthouse are the most selected tourists. 


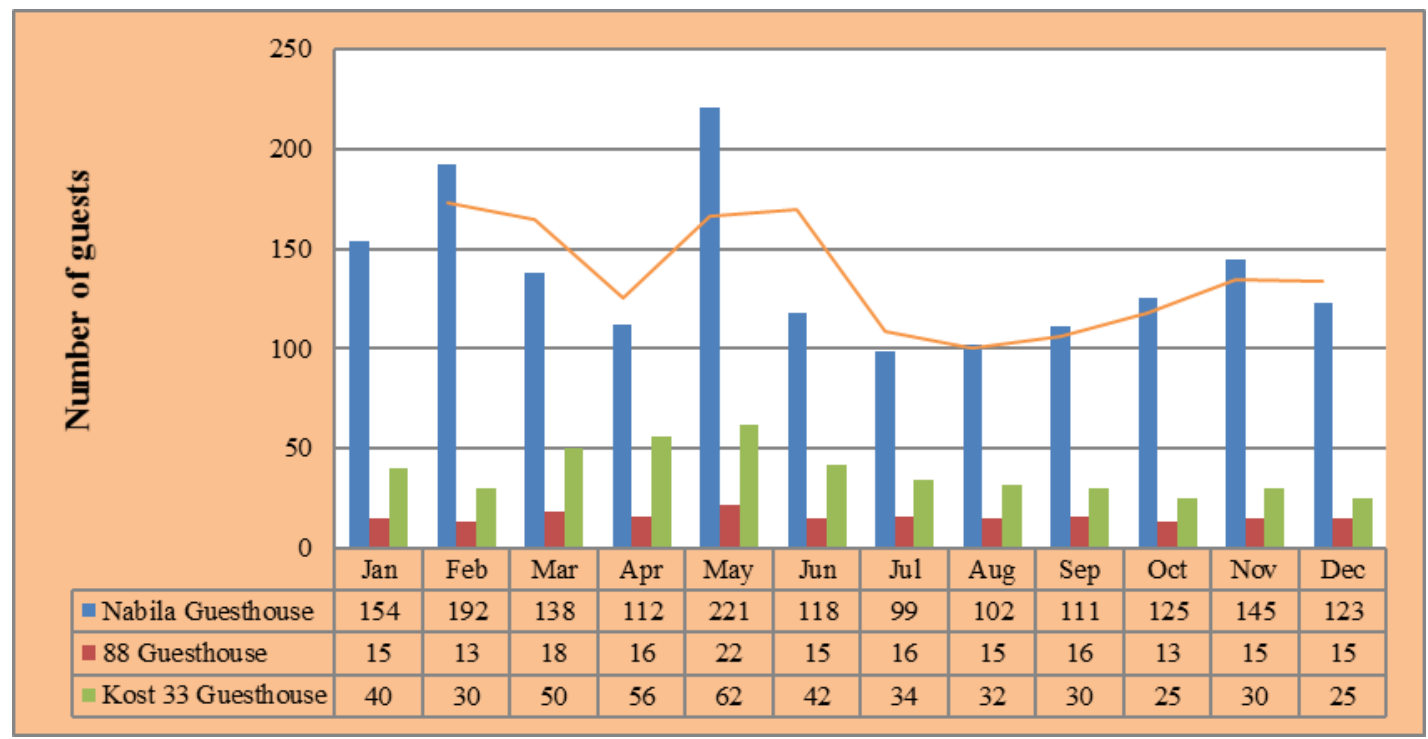

Figure 4. Number of Guests by Guesthouse

Source: Youth, Sports, Culture and Tourism Office of Langsa Municipality, 2017

The increasing number of tourist arrivals, both based on tourist objects and hotel and guesthouse accommodation, show the interest of tourists visiting the Municipality of Langsa higher. To that end, the government, business, and society need synergy in building tourism in the Municipality of Langsa. Tourism development, in addition to spurring economic growth, can also reduce unemployment, increase income, and reduce the level of poverty.

\section{Conclusion}

This study concludes that there is six main tourist object in Langsa Municipality that is mangrove forest, City Forest Park, Bamboo Spiky Park, Mutiara Water Park, Vitra Tirta Raya Swimming Pool, and culinary center. The tourist objects have been equipped with various supporting facilities, namely parking lots, toilets, Islamic prayer rooms, cafeteria, and gazebo. But in the area of mangrove forest and the City Forest Park has not been available Islamic prayer room and cafeteria. The number of tourist arrivals based on attractions in the Municipality of Langsa, from month to month during 2016, is increasing. The most visited attractions are City Forest Park, then mangrove forests, culinary centers, Vitra Tirta Raya Swimming Pool, and Mutiara Water Park. Increased number of tourist arrivals, especially on tourist objects managed by government companies caused by the better management of tourist areas and supporting facilities. Also, the number of tourist arrivals by hotels, guesthouses, and inns is increasing.

The increasing number of tourist arrivals, both based on tourist objects and hotel and lodging accommodation, shows the interest of tourists visiting the Municipality of Langsa higher. To that end, the government, business, and society need synergy in building tourism in the Municipality of Langsa. The growth of tourism, in addition to spurring economic growth, can also reduce unemployment, increase income, and reduce the level of poverty.

The Municipal Government of Langsa has sought to develop tourism with all its facilities to address some development challenges, including poverty reduction, local economic development, and sustainable management of natural resources and the environment. It requires the participation of all stakeholders, including the community in 
developing the tourism sector, along with increasing the quantity and quality of human resources supporting the tourism sector.

\section{Acknowledgment}

This research project is funded by Universitas Samudra under the Applied Higher Education Research scheme.

\section{References}

Alves, S., Roberto, A., \& Nogueira, R. (2015). Towards a sustainable tourism competitiveness measurement model for municipalities : Brazilian empirical evidence. PASOS Journal of Tourism and Cultural Heritage, 13(6), 1337-1353.

Amin, M.A.S., and Priansyah, P. (2019). Marketing Communication Strategy to Improve Tourism Potential. Budapest International Research and Critics Institute (BIRCIJournal): Humanities and Social Sciences, 160-166.

Amir, A. F., Ghapar, A. A., Jamal, S. A., \& Ahmad, K. N. (2015). Sustainable Tourism Development: A Study on Community Resilience for Rural Tourism in Malaysia. In Procedia - Social and Behavioral Sciences (Vol. 168, pp. 116-122). https://doi.org/10.1016/j.sbspro.2014.10.217

Ben Aissa, S., \& Goaied, M. (2017). Performance of Tourism Destinations: Evidence from Tunisia. Journal of Hospitality and Tourism Research, 41(7), 797-822. https://doi.org/10.1177/1096348014550870

Benur, A. M., \& Bramwell, B. (2015). Tourism product development and product diversification in destinations. Tourism Management, 50, 213-224. https://doi.org/10.1016/j.tourman.2015.02.005

Chen, H., \& Rahman, I. (2017). Cultural tourism: An analysis of engagement, cultural contact, memorable tourism experience and destination loyalty. Tourism Management Perspectives, (October), 0-1. https://doi.org/10.1016/j.tmp.2017.10.006

Dogru, T., \& Bulut, U. (2018). Is tourism an engine for economic recovery? Theory and empirical evidence. Tourism Management, 67, 425-434. https://doi.org/10.1016/j.tourman.2017.06.014

Galí, N., Camprubí, R., \& Donaire, J. A. (2017). Analysing tourism slogans in top tourism destinations. Journal of Destination Marketing and Management, 6(3), 243-251. https://doi.org/10.1016/j.jdmm.2016.04.004

Gokovali, U., \& Bahar, O. (2006). Contribution of Tourism to Economic Growth: A Panel Data Approach. Anatolia, 17(2), 155-167. https://doi.org/10.1080/13032917.2006.9687184

Khodadadi, M. (2016). Challenges and opportunities for tourism development in Iran: Perspectives of Iranian tourism suppliers. Tourism Management Perspectives, 19(June 2010), 90-92. https://doi.org/10.1016/j.tmp.2016.05.001

Kršák, B., Tobisová, A., \& Sehnálková, M. (2014). Education in Information Technology as a Tool for Tourism Development. In Procedia - Social and Behavioral Sciences (Vol. 116, pp. 1096-1100). https://doi.org/10.1016/j.sbspro.2014.01.351

Liu, J., Nijkamp, P., Huang, X., \& Lin, D. (2017). Urban livability and tourism development in China: Analysis of sustainable development by means of spatial panel data. Habitat International, 68, 99-107. https://doi.org/10.1016/j.habitatint.2017.02.005

Moghavvemi, S., Woosnam, K. M., Paramanathan, T., Musa, G., \& Hamzah, A. (2017). The effect of residents' personality, emotional solidarity, and community commitment on 
support for tourism development. Tourism Management, 63, 242-254. https://doi.org/10.1016/j.tourman.2017.06.021.

Prasetyo, G., Joebagio, H., and Yamtinah, S. (2019). Modern Paradigm: Democratic Skills in a Higher Order Thinking Skills Frame. Budapest International Research and Critics Institute (BIRCI-Journal) : Humanities, 150-159

Syahrin, A. (2018). Culture Repertoire in Expressive Written Language : Study of Hypothesis of Edward Sapir and Benyamin Lee Whorf. Budapest International Research in Linguistics and Education Sciences (BirLE) Journal, 23-28.

Welford, R., \& Ytterhus, B. (2004). Sustainable development and tourism destination management: A case study of the Lillehammer region, Norway. International Journal of Sustainable Development \& World Ecology, 11(4), 410-422. https://doi.org/10.1080/13504500409469843

Wu, B., Zhu, H., \& Xu, X. (2000). Trends in China's domestic tourism development at the turn of the century. International Journal of Contemporary Hospitality Management, 12(5), 296-299.

Zhou, L., Chan, E., \& Song, H. (2017). Social capital and entrepreneurial mobility in earlystage tourism development: A case from rural China. Tourism Management, 63, 338350. https://doi.org/10.1016/j.tourman.2017.06.027 